\title{
PROFIL SDS-PAGE DAN AKTIVITAS LISOZIM PUTIH TELUR AYAM LOKAL TERMODIFIKASI PANAS
}

\section{The SDS-PAGE and Activity of Heat Modified Lysozyme of Local Chicken Egg White}

\author{
Syahrizal Nasution ${ }^{1 *}$, Didah Nur Faridah², Eni Kusumaningtyas ${ }^{3}$, Zakiah Wulandari ${ }^{4}$, \\ Harsi Dewantari Kusumaningrum ${ }^{2 *}$
}

1) Program Studi Teknologi Pangan, Institut Teknologi Sumatera, JI Terusan Ryacudu

Way Huwi, Lampung Selatan 35365

2) Departemen Ilmu dan Teknologi Pangan, Fakultas Teknologi Pertanian, IPB University, JI Darmaga PO Box 220, Bogor 16002

3) Balai Besar Penelitian Veteriner, JI RE Martadinata No. 30, Bogor 16114

4) Departemen Ilmu Produksi dan Teknologi Peternakan, Fakultas Peternakan,

IPB University Bogor, JI Darmaga, Bogor 16680

*Penulis korespondensi, email: syahrizal.nasution@tp.itera.ac.id,

h_kusumaningrum@apps.ipb.ac.id

\begin{abstract}
ABSTRAK
Lisozim adalah enzim hidrolase yang bisa diisolasi dari putih telur ayam. Penelitian bertujuan untuk mengarakterisasi lisozim termodifikasi dari putih telur ayam lokal dengan SDS-PAGE dan mengukur aktivitas lisozimnya. Lisozim dari putih telur ayam Sentul yang terisolasi kemudian dimodifikasi dengan perlakuan panas. Lisozim dikarakterisasi dengan SDS-PAGE. Aktivitas lisozim diujikan terhadap Micrococcus lysodeikticus. Profil SDS-PAGE menunjukkan lisozim masih memunculkan sedikit ovotransferin dan ovalbumin sebelum dimodifikasi. Perlakuan suhu $60^{\circ} \mathrm{C}$ tidak mengubah profil SDS-PAGE dan hasilnya mirip seperti lisozim terisolasi awal tetapi perlakuan suhu $75^{\circ} \mathrm{C}$ menyebabkan ovotransferin menghilang. Setelah perlakuan suhu $90^{\circ} \mathrm{C}$, selain ovotransverin menghilang, protein baru muncul yang diduga lisozim berbentuk dimer. Profil SDS-PAGE lisozim termodifikasi menjelaskan lisozim tetap mempertahankan aktivitasnya walaupun terjadi perubahan profil lisozim.
\end{abstract}

Kata kunci: SDS-PAGE, Lisozim, Telur Ayam Lokal, Aktivitas Enzimatis, Micrococcus lysodeikticus

\begin{abstract}
Lysozyme is a hydrolase enzyme that can be isolated from the chicken egg white. The research aimed to characterize the lysozyme from the local chicken egg white with SDSPAGE and measure the lysozyme activity. Isolated lysozyme from Sentul chicken egg white was modified with heat treatment. Lysozyme was characterized with SDS-PAGE. The lysozyme activity was measured using Micrococcus lysodeikticus. The SDS PAGE profile showed the lysozyme still has a little ovotransferrin and ovalbumin before modified. The $60^{\circ} \mathrm{C}$ heat treatment showed no change on the SDS-PAGE profile as same as the isolated lysozyme but after $75^{\circ} \mathrm{C}$ heat treatment, made the ovotransferrin disappear. After $90^{\circ} \mathrm{C}$ heat treatment not only did the ovotransferrin disappear, the new protein that suggested being lysozyme in the dimer form also appeared. The SDS-PAGE profile of modified lysozyme
\end{abstract}


explained the lysozyme still keeps the lysozyme activity although the lysozyme protein profile has changed.

Keywords: SDS-PAGE, Lysozyme, Local Chicken Egg, Enzymatic Activity, Micrococcus lysodeikticus

\section{PENDAHULUAN}

Pemanfaatan sumber daya alam Indonesia secara mandiri saat ini masih kurang. Hal tersebut memicu produksi hasil sumber daya alam berupa bahan baku lokal menjadi rendah. Produk yang digunakan banyak berasal dari bahan baku luar, bukan berasal dari bahan baku lokal Indonesia.Walaupun demikian, bahan baku lokal dari sumber daya alam Indonesia terus mengalami perkembangan dari berbagai aspek termasuk penelitianpenelitian yang dilakukan. Ayam lokal merupakan salah satu sumber daya alam Indonesia yang dapat dimanfaatkan dan terus dikembangkan. Ayam lokal pernah menjadi produsen utama telur di Indonesia hingga tahun 1970-an. Ayam lokal tersebut sangat beragam dan memiliki potensi produksi telur yang besar. Produksi telur ayam lokal pada tahun 2017 mencapai $10 \%$ dari keseluruhan produksi telur di Indonesia. Produksi telur ayam lokal tersebut juga selalu mengalami peningkatan. Persentase peningkatan produksi telur ayam lokal dari tahun 2016 ke tahun 2017 mencapai 7.23\% dan lebih tinggi dibandingkan persentase peningkatan produksi telur ayam Ras yang hanya sebesar $2.79 \%$ (DJPKH, 2017). Salah satu jenis ayam lokal yang berkontribusi terhadap peningkatan telur tersebut adalah ayam Sentul.

Ayam Sentul berkontribusi terhadap peningkatan produksi telur di Indonesia karena menghasilkan telur sebanyak 118-140 butir/tahun. Ayam Sentul mampu memproduksi telur hingga 30 butir dalam satu periode (20-35 hari) dengan bobot telur sekitar $40.7 \pm 3$ gram/butir (KMP, 2013). Ayam Sentul juga memiliki keunggulan lainnya yaitu memiliki bobot telur utuh (40.7 gram), bobot kuning telur (15.1 gram), dan bobot putih telur (15.7 gram) (Hidayat dan Sopiyana 2013). Adapun berdasarkan BPPP (2017) telur ayam Sentul hasil seleksi memiliki bobot telur hingga mencapai $44.82 \pm 4$ gram/butir. Walaupun demikian, telur ayam Sentul memiliki karakteristik warna kerabang coklat keputihan yang mirip dengan telur ayam lokal lain. Telur ayam Sentul diproduksi oleh induk ayam Sentul betina yang merupakan salah satu ayam lokal hasil domestikasi ayam hutan merah (Gallus gallus) oleh penduduk Ciamis (Nataamijaya 2010). Ayam Sentul telah diakui sebagai plasma nuftah melalui SK Mentan RI No. 689/Kpts.PD410/2/2013 tentang penetapan ayam Sentul sebagai ayam rumpun lokal Indonesia asal Ciamis. Selain itu, melalui SK Mentan RI No. 39/Kpts/PK.020/1/2017 telah ditetapkan galur ayam Sensi-1 Agrinak hasil seleksi. Hal ini menunjukkan bahwa penggunaan telur ayam Sentul telah mendukung kemandirian pangan sesuai UU RI No. 18 Tahun 2012.

Lisozim merupakan salah satu protein yang bisa diisolasi dari putih telur (Gyawali dan Ibrahim, 2014) dan dapat digunakan secara komersial sebagai antibakteri atau pengawet karena struktur primernya stabil pada suhu panas dan $\mathrm{pH}$ rendah. Lisozim termasuk ovoantimicrobials asal unggas yang bersifat tidak toksik (Carrillo et al. 2016) sehingga diakui sebagai bahan tambahan pangan dengan status Generally Recognized as Safe (GRAS). Lisozim dapat digunakan secara langsung pada pangan, dikombinasi dengan antimikroba lain, maupun ditambahkan pada kemasan edibel (Valdes et al. 2017) untuk meningkatkan keamanan pangan, selain mencegah kerusakan pangan. Lisozim banyak diteliti aplikasinya (Kijowski et al. 2002; Herath et al. 2015; Asmaa et al. 2017) seperti pada keju, sayuran, daging, ikan, dan susu. Lisozim berfungsi sebagai antibakteri karena mampu merusak peptidoglikan dinding sel bakteri Gram positif (Susanto 2012; Callewaert et al. 2012) seperti Staphylococcus aureus, Listeria monocytogenes (Rawdkuen et al. 2012; Wulandari et al. 2015) dan Clostridium botulinum (Hughey dan Johnson, 1987). Aktivitas antibakteri lisozim tersebut setelah diisolasi memiliki keterbatasan aktivitas hanya pada bakteri Gram positif, padahal kontaminan pangan bisa berasal dari bakteri Gram negatif (Nasution et al., 2019). 
Hal tersebut memicu penelitian-penelitian yang dilakukan dengan modifikasi lisozim untuk meningkatkan aktivitas antibakteri agar mampu membunuh bakteri Gram negatif (Aminlari et al. 2014; Nasution et al., 2020) yang lebih resisten karena dinding selnya dilapisi oleh lipopolisakarida.

Lisozim juga diketahui sebagai enzim karena dapat menghidrolisis ikatan glikosidik pada peptidoglikan membran sel Micrococcus lysodeikticus. Lisozim sebagai enzim termasuk ke golongan enzim hidrolase. Aktivitas enzimatis lisozim tersebut dikenal sebagai aktivitas muramidase, hydrolytic activity, aktivitas enzimatis lisozim, atau aktivitas lisozim. Aktivitas lisozim tersebut didefinisikan sebagai penurunan turbiditas suspensi dari Micrococcus lysodeikticus yang diamati menggunakan spektrofotometer $450 \mathrm{~nm}$. Adapun satu unit lisozim didefinisikan sebagai penurunan absorbansi sebesar 0.001 per menit (Nasution, 2019). Aktivitas lisozim perlu diketahui untuk mendefinisikan aktivitas enzimatis lisozim. Berdasarkan uraian tersebut, pengukuran aktivitas lisozim ini dilakukan untuk mengetahui aktivitas lisozim yang dihasilkan dari hasil perlakuan modifikasi panas untuk peningkatan aktivitas antibakteri lisozim. Karakaterisasi terhadap struktur primer lisozim sebagai protein dengan SDS-PAGE juga dilakukan dengan pewarnaan silver untuk mengetahui perubahan profil lisozim dan mengetahui hubungannya terhadap aktivitas lisozim yang dihasilkan.

\section{BAHAN DAN METODE}

\section{Bahan}

Bahan lisozim yang digunakan dalam penelitian ini berasal dari lisozim kering beku yang telah diisolasi dari putih telur Ayam Sentul yang diperoleh dari Balai Penelitian Ternak Ciawi-Bogor berumur 1-2 hari. Standar lisozim (L-6876, from chicken egg white, 47,000 unit/mg solid, EC 3.2.1.17) dari Sigma Chemical Co. Subtrat Micrococcus lysodeikticus ATCC 4698 (Sigma-Alderich) untuk aktivitas lisozim. Standar protein berat molekul rentang 10-250 kD (Biorad) untuk marker SDS-PAGE. Buffer potasium posfat (KH2PO4-NaOH) sebagai pelarut lisozim. Bahan SDS-PAGE meliputi polyacrylamide gel electrophoresis (separating gel $12.5 \%$ dan stacking gel $4 \%$ terdiri atas akrilamide $\left(\mathrm{C}_{3} \mathrm{H}_{5} \mathrm{NO}\right)$, buffer tris $\left(\mathrm{C}_{4} \mathrm{H}_{11} \mathrm{NO}_{3}\right)$, aquabides, ammonium persulfat $\left(\left(\mathrm{NH}_{4}\right)_{2} \mathrm{~S}_{2} \mathrm{O}_{8}\right.$, APS $)$, tetrametilendiamin (TEMED) dan sodium dodecyl sulfate (SDS)), running buffer (tris-glisin-SDS), larutan fiksasi (metanol $\left(\mathrm{CH}_{3} \mathrm{OH}\right)$, asam asetat $\left(\mathrm{C}_{10} \mathrm{H}_{26} \mathrm{~N}_{2} \mathrm{O}_{8}\right)$, formalin $\left(\mathrm{CH}_{2} \mathrm{O}\right)$, aquabides), larutan sensitizing $\left(\mathrm{Na}_{2} \mathrm{~S}_{2} \mathrm{O}_{3}\right.$, aquabides), larutan pencuci (etanol $\left(\mathrm{C}_{2} \mathrm{H}_{5} \mathrm{OH}\right) 20 \%$ ), larutan developing $\left(\mathrm{NaCO}_{3}\right.$, formalin, $\left.\mathrm{NaS}_{2} \mathrm{O}_{3}\right)$, stop solution (asam asetat glasial, aquabides), larutan pewarna silver (perak nitrat $\left(\mathrm{AgNO}_{3}\right) 0.1 \%$ ), asam trifluoroacetat $\left(\mathrm{C}_{2} \mathrm{HF}_{3} \mathrm{O}_{2}\right)$, dan asetonitril $\left(\mathrm{C}_{2} \mathrm{H}_{3} \mathrm{~N}\right)$. Buffer sampel untuk running SDS-PAGE terdiri atas $2 \mathrm{~mL}$ mercaptoethanol, $4 \mathrm{~mL}$ gliserol, 0.3 gram buffer, $2 \mathrm{~mL}$ bromfenol blue $(0.1 \% \mathrm{w} / \mathrm{v}$ dalam 20 $\mathrm{mL}$ aquabides), dan 0.92 gram SDS

\section{Alat}

Alat yang digunakan dalam penelitian ini yaitu waterbath (GFL 1003) untuk perlakuan modifikasi panas, refrigerator (LG) untuk penurunan suhu setelah modifikasi, spektrofotometer UV-vis (Uv mini 1240, Shimadzu) untuk pengukuran absorbansi aktivitas lisozim, dan alat electrophoresis (Biorad) untuk running SDS-PAGE.

\section{Desain Penelitian}

Penelitian ini dilakukan dengan menyiapkan bahan utama dan bahan lainnya serta alat-alat yang dibutuhkan. Perlakuan modifikasi panas dilakukan dengan tiga suhu yang berbeda. Pengukuran aktivitas lisozim dan SDS-PAGE dilakukan terhadap tiga sampel lisozim termodifikasi, satu lisozim sebelum termodifikasi, dan satu lisozim standar. 


\section{Tahapan Penelitian}

Penelitian ini terdiri atas tiga tahapan yaitu tahapan modifikasi lisozim dengan panas, tahapan pengukuran aktivitas lisozim, dan tahapan karakterisasi lisozim dengan SDSPAGE.

\section{Metode Modifikasi Lisozim dengan Perlakuan Panas}

Lisozim diberikan perlakuan panas berdasarkan modifikasi Carrillo et al. (2018). Lisozim masing-masing $6 \mathrm{mg} / \mathrm{mL}$ di dalam $10 \mathrm{~mL} 10 \mathrm{mM}$ buffer potassium phosphate $\mathrm{pH} 7$ dipanaskan di waterbath pada suhu $60^{\circ} \mathrm{C}, 75^{\circ} \mathrm{C}$, dan $90^{\circ} \mathrm{C}$ selama 20 menit. Larutan lisozim dimasukkan ke dalam refrigerator $\left(4^{\circ} \mathrm{C}\right)$ segera setelah selesai dipanaskan. Larutan lisozim tersebut kemudian diuji aktivitas lisozimnya.

\section{Metode Pengukuran Aktivitas Lisozim}

Lisozim sebelum dan sesudah modifikasi diukur aktivitas lisozimnya mengacu metode Shugar berdasarkan modifikasi Carrillo dan Ramos (2018). Suspensi substrat $0.015 \%$ disiapkan dengan mencampurkan $0.15 \mathrm{mg} / \mathrm{mL}$ Micrococcus lysodeikticus ATCC 4698 kering di dalam $50 \mathrm{mM}$ buffer potassium phosphate $\left(\mathrm{pH} 6.24,25^{\circ} \mathrm{C}\right)$. Substrat disesuaikan agar terbaca 0.6-0.7 terhadap blank pada $450 \mathrm{~nm}$. Larutan lisozim $(0.7 \mathrm{mg} / \mathrm{mL})$ dibuat di dalam buffer potassium phosphate $\left(\mathrm{pH} 6.24,8^{\circ} \mathrm{C}\right)$. Sebanyak $1.5 \mathrm{~mL}$ Micrococcus lysodeikticus dan $0.1 \mathrm{~mL}$ larutan lisozim dimasukkan ke dalam kuvet. Kuvet yang berisikan Micrococcus lysodeikticus ditambahkan buffer $0.10 \mathrm{~mL}$ sebagai blank. Sampel di dalam kuvet dihomogenisasi dan diukur penurunan absorbansi $(450 \mathrm{~nm})$ selama 5 menit. Satu unit lisozim didefinisikan penurunan absorbansi per menit sebanyak 0.001 .

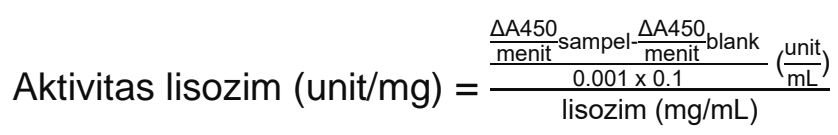

\section{Metode Karakterisasi Lisozim dengan SDS-PAGE}

Lisozim sebelum dan sesudah modifikasi panas dikarakterisasi dengan sodium dodecyl polyacrylamide gel electrophoresis (SDS-PAGE) mengacu metode Laemmli berdasarkan modifikasi Carrillo et al. (2014). Gel electrophoresis menggunakan gel pemisah $2.5 \%$ dan gel penggumpal 4\%. Sampel dilarutkan (1:2) di dalam buffer sampel. Campuran dipanaskan $\left(95^{\circ} \mathrm{C}, 5\right.$ menit). Sampel lisozim sebanyak $50 \mu \mathrm{L}$ di-running pada alat electrophoresis selama 3.5 jam pada voltase 60 volt. Setelah sampai batas bawah, gel direndam dengan larutan fiksasi, dicuci dengan washing solution, dibilas dengan aquabides, direndam dengan larutan sensitizing, dicuci dengan aquabides, diwarnai dengan perak nitrat, dicuci dengan aquabides, direndam dengan larutan developing, ditambahkan stop solution, dan dicuci dengan aquabides. Hasil gel di-scan dan berat molekul protein diukur berdasarkan kurva standard marker.

\section{Prosedur Analisis}

Analisis dilakukan terhadap data aktivitas lisozim dan ditampilkan berupa nilai rata-rata \pm standar deviasi yang diperoleh dari rumus aktivitas lisozim, profil SDS-PAGE pada gel hasil scan dijelaskan berdasarkan pita yang muncul dan berat molekul diukur berdasarkan kurva standard marker pada profil SDS-PAGE. 
HASIL DAN PEMBAHASAN

\section{Aktivitas Lisozim Putih Telur Ayam Sentul Termodifikasi Panas}

\begin{tabular}{lc}
\multicolumn{2}{c}{ Tabel 1. Aktivitas Lisozim Termodifikasi Panas } \\
\hline Jenis Lisozim & Aktivitas Lisozim (unit/mg) \\
\hline Lisozim standar (A) & $37571 \pm 11631^{\mathrm{a}}$ \\
Lisozim terisolasi sebelum modifikasi (B) & $4778 \pm 1835^{\mathrm{b}}$ \\
Lisozim termodifikasi $60^{\circ} \mathrm{C}$ (C) & $10556 \pm 4501^{\mathrm{b}}$ \\
Lisozim termodifikasi $75^{\circ} \mathrm{C}(\mathrm{D})$ & $9000 \pm 333^{\mathrm{b}}$ \\
Lisozim termodifikasi $90^{\circ} \mathrm{C}(\mathrm{E})$ & $7889 \pm 1170^{\mathrm{b}}$ \\
\hline
\end{tabular}

Angka yang diikuti huruf yang sama secara vertikal tidak berbeda nyata $(p>0.05)$

Aktivitas lisozim terisolasi sebelum modifikasi (B) dan semua lisozim sesudah modifikasi (C, D, E) lebih rendah dibandingkan lisozim standar $(A)$ pada Tabel 1. Aktivitas ini dipengaruhi oleh kemurnian lisozim terisolasi yang ditampilkan pada profil SDS-PAGE pada Gambar 1. Profile SDS-PAGE menunjukkan lisozim standar lebih murni dibandingkan lisozim terisolasi. Walaupun demikian, hal ini juga diduga karena konsentrasi lisozim sebagai protein dengan struktur tersier (globular) pada lisozim berkurang. Hal ini dijelaskan berdasarkan pengujian reversed phase high-performance liquid chromatography (RP-HPLC) yang telah dilakukan Nasution (2019). Pengujian RP-HPLC berkaitan dengan struktur globular lisozim karena dalam pengujian tersebut tidak dilakukan denaturasi struktur lisozim. Berkurangnya lisozim globular dengan sisi aktif glutamat 35 dan aspartat 52 untuk menghidrolisis subtrat menyebabkan aktivitas lisozim menjadi lebih rendah. Oleh karena itu, untuk menghasilkan lisozim dengan aktivitas yang lebih tinggi perlu diperhatikan kemurnian dan struktur globular lisozim. Perlakuan modifikasi panas yang diberikan pada lisozim terisolasi juga tidak menghasilkan perubahan yang signifikan pada aktivitas lisozim termodifikasi (C, D, E) dibandingkan lisozim sebelum modifikasi (B) (Tabel 1). Hal ini menunjukkan bahwa perlakuan modifikasi panas terhadap lisozim untuk tujuan peningkatan aktivitas antibakteri dapat dilakukan dan tidak memberikan pengaruh terhadap aktivitas lisozim yang dihasilkan.

Modifikasi panas pada penelitian ini berbeda dengan penelitian Lesnierowski et al. (2004) yang menurunkan nilai aktivitas lisozim dengan meningkatnya suhu modifikasi dari $60^{\circ} \mathrm{C}$ hingga $90^{\circ} \mathrm{C}$ secara signifikan. Penelitian Carrillo et al. (2014) juga menunjukkan bahwa modifikasi panas $90^{\circ} \mathrm{C}$ dan $95^{\circ} \mathrm{C}$ menyebabkan penurunan aktivitas lisozim hingga $41.8 \%$. Penelitian Mine et al. (2004) melaporkan modifikasi panas $90^{\circ} \mathrm{C}$ hanya menyisakan $26 \%$ dari aktivitas lisozim sebelum dimodifikasi. Walaupun demikian, penelitian ini memberikan hasil yang sama dengan penelitian Priyadarshini et al. (2002) yang menunjukkan hasil aktivitas lisozim yang sama sebelum dan sesudah modifikasi dengan perlakuan LTLT (low temperature, long time) suhu $63^{\circ} \mathrm{C}$ selama 30 menit dan HTST (high temperature, short time) suhu $74^{\circ} \mathrm{C}$ selama 16 detik. Hal ini menunjukkan bahwa aktivitas lisozim setelah modifikasi panas juga dipengaruhi oleh jenis dan volume larutan yang digunakan selama modifikasi lisozim, selain suhu dan waktu modifikasi.

Aktivitas lisozim yang dihasilkan juga dipengaruhi oleh faktor lain seperti indukan ayam, sistem pemeliharaan, dan periode bertelur. Penelitian Trziszka et al. (2007) menunjukkan bahwa indukan ayam dan sistem pemeliharaan memberikan pengaruh nyata secara statistik terhadap aktivitas lisozim yang dihasilkan. Penelitiannya menunjukkan bahwa dengan pemberian pakan yang sama, aktivitas lisozim tertinggi diperoleh dari telur yang diproduksi oleh ayam pada sistem pemeliharaan battery dibandingkan sistem free range dan litter. Selain itu, telur dari indukan ayam Lohmann dari penelitian tersebut menghasilkan aktivitas lisozim yang lebih tinggi dibandingkan dengan telur ayam Green-leg. Aktivitas lisozim yang dihasilkan penelitian tersebut juga lebih tinggi pada periode spring hingga summer dibandingkan periode winter. Penelitian Kopec et al. (2005) menambahkan 
pertimbangan pemberian jenis pakan karena perbedaan pakan yang diberikan menyebabkan perubahan aktivitas lisozim.

\section{Profil SDS-PAGE Lisozim Termodifikasi Panas}

Karakterisasi lisozim termodifikasi dengan metode SDS-PAGE bertujuan untuk melihat pengaruh modifikasi panas terhadap struktur primer lisozim (setelah denaturasi suhu $95^{\circ} \mathrm{C}$, 5 menit) dan hubungannya terhadap aktivitas lisozim yang dihasilkan. Pita SDS-PAGE dengan pewarnaan silver (bagian d, e, dan f) menunjukkan bahwa semua modifikasi panas pada lisozim tetap mempertahankan struktur primer lisozim yang dibuktikan oleh pita lisozim yang tidak hilang $(14.70 \pm 0.43 \mathrm{kD})$, walaupun muncul sedikit perubahan pada profil pita SDS-PAGE yang dihasilkan. Modifikasi panas $60^{\circ} \mathrm{C}$ (bagian $\mathrm{d}$ ) belum menyebabkan perubahan pita pada gel yang terbentuk melainkan tetap mempertahankan profil yang mirip dengan profil lisozim terisolasi sebelum modifikasi panas (bagian c). Hal ini dapat terjadi karena lisozim memiliki 4 jembatan disulfida (Cegielska-Radziejewska et al. 2008) berupa 6Cys-127Cys, 30Cys-115Cys, 64Cys-8-Cys, dan 76 Cys-94Cys sehingga strukturnya stabil. Berbeda dengan modifikasi panas $75^{\circ} \mathrm{C}$ dan $90^{\circ} \mathrm{C}$ (bagian e dan $\mathrm{f}$ ) yang menyebabkan perubahan profil pita pada gel. Perbedaan perubahan profil pita tersebut diduga karena perubahan protein lisozim dapat terjadi setelah diberikan suhu lebih dari suhu denaturasi lisozim $\left(75^{\circ} \mathrm{C}\right)$ (Alleoni, 2006).

Walaupun demikian, Lesnierowski et al. (2004) menyebutkan modifikasi panas $60^{\circ} \mathrm{C}$ pada $\mathrm{pH} 4.4$ sudah menyebabkan munculnya lisozim dimer sebesar $27.2 \%$. Hal tersebut sesuai dengan Lesnierowski et al. (2001) yang melaporkan pada modifikasi panas $60^{\circ} \mathrm{C}$ selama 20 menit menyebabkan terbentuk lisozim dimer secara signifikan dari yang paling tinggi $\mathrm{pH} 5$ dan 6 , kemudian $\mathrm{pH} 4$, dan dilanjutkan $\mathrm{pH} 7$ dan 8 . Hal ini juga menunjukkan bahwa $\mathrm{pH} 7$ yang digunakan dalam penelitian hanya memunculkan pita lisozim berbentuk dimer yang tipis (sedikit) pada profil SDS-PAGE modifikasi $90^{\circ} \mathrm{C}$. Penelitian ini sesuai dengan Carrillo et al. (2014) yang menunjukkan bahwa modifikasi panas $90^{\circ} \mathrm{C}$ dan $95^{\circ} \mathrm{C}$ menghasilkan lisozim berbentuk dimer dan belum dihasilkan pita dimer pada modifikasi panas $60^{\circ} \mathrm{C}$ dan $50^{\circ} \mathrm{C}$. Namun, hal ini berbanding terbalik dengan Vilcacundo et al. (2018) yang menunjukkan bahwa lisozim dimer terbentuk dengan modifikasi panas dengan $\mathrm{pH} 7$ yang lebih tebal dari $\mathrm{pH} 6$.

Keterangan:

a. Marker rentang 10$250 \mathrm{kD}$

b. Lisozim standar

c. Lisozim sebelum modifikasi

d. Lisozim termodifikasi $60^{\circ} \mathrm{C}$

e. Lisozim termodifikasi $75^{\circ} \mathrm{C}$

f. Lisozim termodifikasi $90^{\circ} \mathrm{C}$

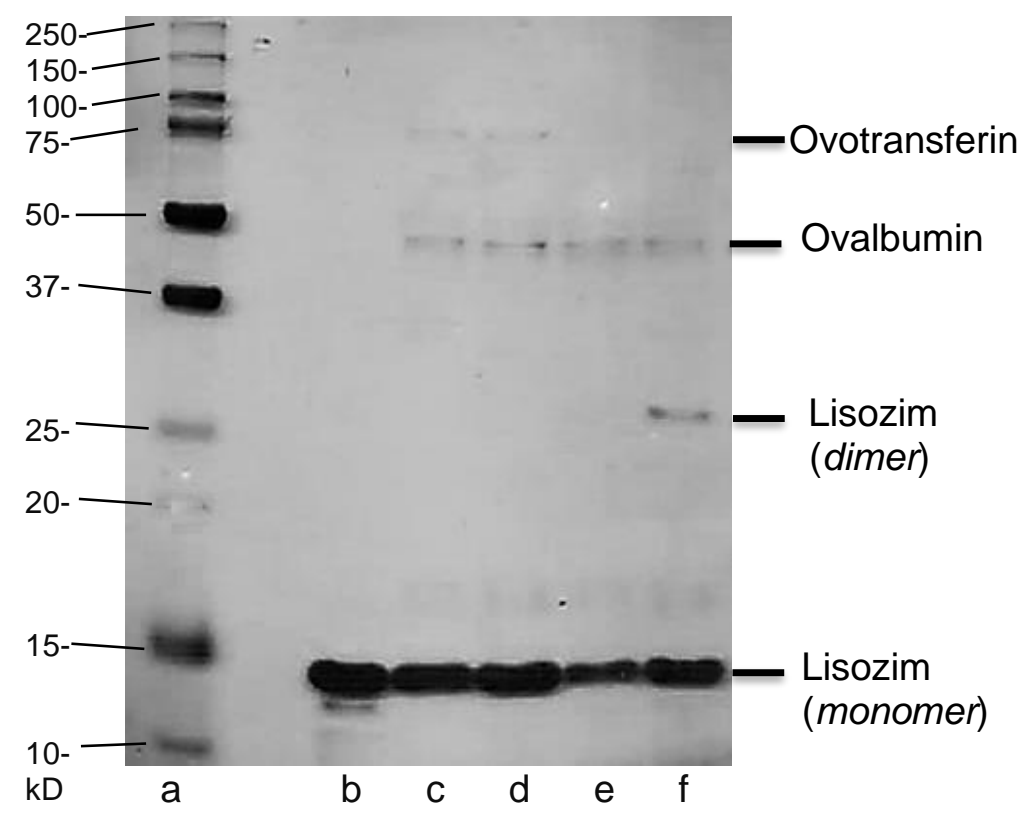

Gambar 1. Profil SDS-PAGE Lisozim Termodifikasi Panas 
Modifikasi panas $75^{\circ} \mathrm{C}$ menyebabkan hilangnya pita ovotransferin yang masih terdapat pada profil SDS-PAGE lisozim terisolasi dan termodifikasi panas $60^{\circ} \mathrm{C}$. Hal ini diduga karena berbagai reaksi yang terjadi selama modifikasi. Berdasarkan perlakuan panas yang diberikan, reaksi yang paling sering diketahui adalah reaksi denaturasi. Alleoni (2006) melaporkan suhu denaturasi ovotransferin $\left(61^{\circ} \mathrm{C}\right)$ lebih rendah dibandingkan suhu denaturasi lisozim $\left(75^{\circ} \mathrm{C}\right)$ dan ovalbumin $\left(84^{\circ} \mathrm{C}\right)$ sehingga denaturasi ovotransferin yang terjadi dapat menyebabkan ovotransferin bereaksi dengan protein lain sehingga membentuk pita yang tidak terdeteksi pada rentang marker 10-25 kD. Walaupun demikian, karakter ini berbeda dengan pita lisozim dan ovalbumin yang tidak hilang pada ketiga perlakuan panas. Modifikasi panas $90^{\circ} \mathrm{C}$ yang lebih tinggi dari suhu denaturasi lisozim bahkan memunculkan pita baru yang merupakan bentuk dimer dari lisozim $(28.62 \pm 0.84 \mathrm{kD})$, selain menyebabkan pita ovotransferin hilang. Lisozim dimer terbentuk dari proses polimerisasi lisozim yang membentuk lisozim dimer secara reversibel. Polimerisasi terjadi pada lisozim terisolasi monomer (bagian c) setelah diberikan modifikasi panas. Hal tersebut sesuai penelitian Lesnierowski et al. (2004) bahwa modifikasi panas memunculkan lisozim dimer yang semakin meningkat dari suhu $60^{\circ} \mathrm{C}$ hingga $90^{\circ} \mathrm{C}$.

Cegielska-Radziejewska et al. (2008) menambahkan lisozim di alam berada dalam bentuk dimer yang reversibel dan ditemukan dalam dua bentuk konformasi di antara suhu $20^{\circ} \mathrm{C}$ sampai $30^{\circ} \mathrm{C}$ dengan titik transisi pada suhu $25^{\circ} \mathrm{C}$. Modifikasi dengan perlakuan panas pada lisozim dapat menghasilkan lisozim dengan bentuk dimer atau polimer dari lisozim sehingga aktivitas lisozim berubah. Suhu yang digunakan pada penelitian ini berada di atas suhu titik transisi tersebut dan di antara suhu denaturasi lisozim (suhu $75^{\circ} \mathrm{C}$ ). Modifikasi panas $60^{\circ} \mathrm{C}, 75^{\circ} \mathrm{C}$, dan $90^{\circ} \mathrm{C}$ selama 20 menit menyebabkan perbedaan perubahan profil pita yang dapat menjelaskan aktivitas lisozim yang sama karena perubahan pita yang hanya sedikit dibandingkan pita lisozim yang muncul.

\section{Berat Molekul Protein-Protein pada Lisozim Termodifikasi Panas}

Tabel 2. Berat Molekul Lisozim dan Protein lain pada SDS-PAGE

\begin{tabular}{lc}
\hline Protein putih telur & Beral molekul (kD) \\
\hline Ovalbumin & $45.25 \pm 1.33$ \\
Ovotransferin & $74.58 \pm 2.19$ \\
Lisozim (monomer) & $14.70 \pm 0.43$ \\
Lisozim (dimer) & $28.62 \pm 0.84$ \\
\hline
\end{tabular}

Berat molekul protein-protein yang dihasilkan pada pita SDS-PAGE ditunjukkan pada Tabel 2. Lisozim yang dimodifikasi memunculkan protein-protein lain dengan berat molekul berbeda dengan lisozim. Lisozim dengan berat molekul $14.70 \pm 0.43 \mathrm{kD}$ menunjukkan berat molekul yang mirip dengan lisozim standar (Gambar 1), serta lisozim menurut Lesnierowski dan Stangierski (2018). Pita SDS-PAGE memunculkan protein dengan berat molekul 45.25 $\pm 1.33 \mathrm{kD}$ (ovalbumin) dan protein dengan berat molekul $74.58 \pm 2.19 \mathrm{kD}$ (ovotransferin) yang mirip dengan ovalbumin dan ovotransferin yang diteliti Lesnierowski dan Stangierski (2018) secara berurutan dengan berat molekul 45 kD dan 76 kD. Adapun protein lain yang muncul pada pita SDS-PAGE adalah lisozim dalam bentuk dimer dengan berat molekul $28.62 \pm 0.84 \mathrm{kD}$ yang mirip dengan penelitian Lesnierowski et al. (2004). Berat molekul lisozim dimer tersebut juga mirip dengan protein ovomucoid dengan berat molekul $28 \mathrm{kD}$ (Lesnierowski dan Stangierski 2018).

\section{SIMPULAN}

Aktivitas lisozim putih telur ayam lokal yang diberikan perlakuan modifikasi panas $\left(60^{\circ} \mathrm{C}, 75^{\circ} \mathrm{C}\right.$, and $\left.90^{\circ} \mathrm{C}\right)$ tetap dapat mempertahankan aktivitas lisozimnya. Profil SDS-PAGE menjelaskan alasan lisozim tetap mempertahankan aktivitasnya karena perubahan profil protein yang muncul pada lisozim termodifikasi yang tidak terlalu banyak. 


\section{UCAPAN TERIMA KASIH}

Penulis menyampaikan terimakasih kepada Balai Penelitian Ternak Ciawi-Bogor dalam penyedian telur Sentul.

\section{DAFTAR PUSTAKA}

Alleoni, A.C.C. (2006). Albumen proteion and fungtional properties of gelatin and foaming. Sce. Agrc., 63(3), 291-298.

Aminlari, L., \& Hashemi, M.M. (2014). Modified Lysozymes as Novel Broad Spectrum Natural Antimicrobial Agents in Foods. Journal of Food Science, 1077-1090. doi:10.1111/17503841.12460

Asmaa, Fayed, M.S., Hala, Ali, \& Yassin, A. (2017). Use of lysozyme to control Staphylococcus aureus and its effect on shelf life of chilled chicken fillet. Animal Health Research Journal, 5(4), 146-152.

[BPPP] Badan Penelitian dan Pengembangan Pertanian. (2017). Ayam Lokal Pedaging Unggul (SenSi-1 Agrinak). http://www.litbang.pertanian.go.id/press/one/56/pdf/SenSi\%201\%20Agrinak.pdf. Tanggal akses: 17/08/2018

Callewaert, L., Herreweghe, J.M.V., Vanderkelen, L., Leysen, S., Voet, A., \& Michiels, C.W. (2012). Guards of the great wall: bacterial lysozyme inhibitors. Trends in Microbiology, 20(10), 501-510. doi:10.1007/s12038-010-0015-5

Carrillo, W. \& Ramos, M. (2018). Identification of antimicrobial peptides of native and heated hydrolysates from hen egg white lysozyme. J. Med. Food,1-12. doi:10.1089/jmf.2017.0132

Carrillo, W., Lucio, A., Gaibor, J., Morales, D., \& Vasquez, G. (2018). Isolation of Antibacterial Hydrolysates from hen egg white lysozyme and identification of antibacterial peptides. J. Med. Food, 1-11. doi:10.1089/jmf.2017. 0134

Carrillo, W., Tubon, J., \& Vilcacundo, R. (2016). Isolation of hen egg white lysozyme by cation exchange chromatography, analysis of its digestibility and evaluation of the inhibition lipid peroxidation in the zebrafish model. Asian J. Pharm. Clin. Res., 9(3), 345-349.

Carrillo, W., García-Ruiz, A., Recio, I., \& Moreno-Arribas, M.V. (2014). Antibacterial activity of hen egg white lysozyme modified by heat and enzymatic treatments against oenological lactic acid bacteria and acetic acid bacteria. J. Food Prot., 77(10), 17321739. doi:10.4315/0362-028X.JFP-14-009

Cegielska-Radziejewska, R., Lesnierowski, G., \& Kijowski, J. (2008). Properties and aplication of egg white lysozyme and its modified preparations-a review. Pol. J. Food Nutr. Sci., 58(1), 5-10.

[DJPKH] Direktorat Jendral Peternakan dan Kesehatan Hewan. (2017). Produksi telur ayam ras petelur menurut provinsi 2013-2017. http://www.pertanian.go.id/ap_pages/mod /datanak. Tanggal akses: 12/12/2017

Gyawali, R \& Ibrahim, S.A. (2014). Natural products as antimicrobial agents. Food Control, 46, 412-429. doi.org/10.1016/j.foodcont.2014.05.047.

Herath, A.H.M.E.I, Priyanath, J.J.M., Ahn, D.U., \& Abeyrathne, E.D.N.S. (2015). Use of lysozyme from chicken egg white as a nitrite replacer in an itlian-type chichken sausage. Fungtional Foods in Health and Disease, 5(9), 320-330.

Hidayat, C. \& Sopiyana, S. (2013). Potensi ayam sentul sebagai plasma nutfah asli Ciamis Jawa Barat. Wartazoa, 20(40), 190-205.

Hughey, V.L. \& Johnson, E.A. (1987). Antimicrobial Activity of lysozyme against bacteria involved in food spoilage and foodborne desease. Applied and Enviromental Microbiology, 53(9), 2165-2170. 
[KMP] Keputusan Menteri Pertanian. (2013). Penetapan rumpun ayam Sentul. 698/Kpts/PD.410/2/2013.http://www.pertanian.go.id/assets/upload/doc/surat\%20kepu tusan\%20MENTAN\%202013.pdf. Tanggal akses: 12/12/2017

Kijowski, J., Marciszewska, C., \& Cegielska-Radziejewska, R. (2002). Quality and microbiological stability of chilled chicken legs treated with lysozyme. Journal of Food and Nutrition Sciences, 11(52), 47-54. doi:10.2478/bvip-2013-0015

Kopec, W., Skiba, T., Korzeniowska, M., Bobak, L., \& Trszka, T. (2005). Activity of protease inhibitors and lysozyme of hens egg depending on feed modification and egg storage. Pol. J. Food Nutr. Sci., 14(55), 79-83

Lesnierowski, G. \& Stangierski, J. (2018). What's new in chicken egg research and technology for human health promotion?-A review. Trends in Food Science \& Technology, 71, 46-51. doi.org/10.1016/j.tifs.2017.10.022

Lesnierowski, G., Cegielska-Radziejewska, R., \& Kijowski, J. (2004). Thermally and chemical-thermillay modified lysozyme and its bacteriostatic activity. World's Poultry Science Journal 60, 303-310. doi:10.1079/WPS200318

Lesnierowski, G., Cegielska-Radziejewska, R., \& Kijowski, J. (2001). Antibacterial activity of thermally medified lysozyme. Elec. J. of Pol. Agr. Universities, 4(2), 1-9. http://www.ejpau.media.pl/volume4/issue2/food/art-17.html

Mine, Y., Ma, F., \& Lauriau, S. (2004). Antimicrobial peptides released by enzymatic hydrolysis of hen egg white lysozyme. Journal of Agricultural and Food Chemistry, 52, 1088-1094. doi:10.1021/jf0345752

Nasution, S. (2019). Peningkatan aktivitas antibakteri lisozim putih telur ayam sentul. Tesis Magister. Ilmu Pangan. Fakultas Teknologi Pertanian. Bogor. IPB University

Nasution, S., Kusumaningtyas, E., Faridah, D.N., Kusumaningrum, H.D. (2019). Lisozim dari putih telur ayam sebagai agen antibakterial. Wartazoa, 28(4), 175-188.

Nasution, S., Faridah, D.N., Kusumaningtyas, E., Wulandari, Z., Kusumaningrum, H.D. (2020). Antibacterial activity and RP-HPLC characteristic of lysozyme from local chicken egg white after modification treatments. Sitanggang, A.B, \& Nuraida L. Facing Future Chalanges: Sustainable Food Safety, Quality, and Nutrition. pp. 84-88. ${ }^{2}$ nd SEAFAST International Seminar, Bogor: Scitepress digital library.

Nataamijaya, A.G. (2010). Pengembangan potensi ayam lokal untuk menunjang peningkatan kesejahteraan petani. Jurnal Litbang Pertanian, 29(4), 131-138.

Priyadarshini, S., \& Kansal, V.K. (2002). Lysozyme activity in buffalo milk:efect of lactation period, parity, mastitis, season in India, ph and milk processing heat treatment. Asian-Aust. J. Anim., 5(6), 895-899.

Rawdkuen, S., Suthiluk, P., Kamhangwong, D., \& Banjakul, S. (2012). Antimicrobial activity of some potential active compounds against food spoilage microorganisms. African Journal of Biotechnology, 11(74), 13914-13921. doi:10.5897/AJB12.1400

Susanto, E. (2012). Kajian ekstraksi lisozim putih telur dengan menggunakan mika. Jurnal Ternak, 3:2, 19-24.

Trziszka, T., Dobrzanski, Z., Skiba, T., \& Kopec, W. (2007). Effects of breeding and housing systems of layers on egg quality and the activity of cystatin and lysozyme. Pol. J. Food Nutr. Sci., 57(4), 583-586.

Wulandari, Z., Fardiaz, D., Budiman, C., Suryati, T., \& Herawati, D. (2015). Purification of egg white lysozyme from indonesian kampung chicken dan ducks. Media Peternakan, 38(1), 18-26. doi.org/10.5398/medpet.2015.38.1.18

Valdes, A., Ramos, M., Beltrán, A., Jiménez, A., \& Garrigós, M.C. (2017). State of the art of antimicrobial edible coatings for food packaging applications. Coatings, 7(56),1-23. doi:10.3390/coatings7040056

Vilcacundo, R., Mendez, P., Reyes, W., Romero, H., Pinto, A., Carrillo, W. (2018). Antibacterial activity of he egg white lysozyme denaturated by thermal and chemical treatments. Scientia Pharmaceutica, 86(48), 1-17. doi:10.3390/sciphar m86040048. 